\title{
IN THE WAKE OF WINSTON - CLIMATE CHANGE, MOBILITY AND RESILIENCY IN FIJI
}

\author{
A. ROWAN GARD \& JOELI VEITAYAKI \\ Centre for Pacific Studies, University of St Andrews, United Kingdom \& School of Marine Studies, \\ University of the South Pacific, Fiji.
}

\begin{abstract}
When tropical cyclone Winston hit Fiji on 20 February 2016, it became the strongest storm recorded in the southern hemisphere and the second strongest storm ever recorded in the world. Forty-four people died as a result of the superstorm, and the ongoing governmental recovery plans have estimated nearly three billion Fijian dollars ( $£ 1.1$ billion) in damages. Fijian Prime Minister Frank Bainimarama, in a national address following Winston, stated 'almost no part of our nation has been left unscarred'. This paper explores the adaptation measures for extreme weather and climate change in Fiji following Winston, as well as the author's experiences both as a survivor of Winston and as a volunteer aid-relief worker living in Suva, the Fijian capital, at the time of the superstorm. Notably, Winston struck 5 days after Fiji became the first nation to ratify the United Nations Climate deal agreed to by 195 nations in Paris in December 2015. Many Pacific island nations have played a vital role in leading the global dialogue on climate change. In the lead up to the Paris summit, Prime Minister Bainimarama, stressed that 'unless the world acts decisively in the coming weeks to begin addressing the greatest challenge of our age, then the Pacific, as we know it, is doomed.' This is undoubtedly true and a global response is desperately needed, but equally true is the importance for such a reaction to be a cultural and faith-integrated process across multiple scales, ranging from village and community to regional, in scope. One critical aspect of extreme weather and climate change response in the Pacific is migration. However, the impacts of migration include organizing, adaptation and urban poverty, a further source of vulnerability. Consequently, human mobility in response to extreme weather and climate change is far more complex than originally addressed and is deserving of deeper consideration.

Keywords: climate change, extreme weather, faith-based organisations (FBOs), fiji, mobility, resiliency, tropical cyclone Winston.
\end{abstract}

\section{TROPICAL CYCLONE WINSTON}

In the flickering candlelight I stare at the ceiling and wonder if the roof will peel away in the incredible winds of tropical cyclone Winston. On this particular Saturday night in Suva, the Fijian capital, the tall palm trees in the backyard crash to the ground in the devastating winds and it feels as if the world is attempting to invert itself, as Winston generates gusts of wind recorded at $200 \mathrm{mph}$ and average wind speeds of $143 \mathrm{mph}$ [1].

Winston was a Category 5 superstorm of unprecedented strength and destruction. Dozens of people were killed, buildings were stripped to their foundations and towns reduced to rubble, leaving many in abject poverty.

For months after Winston, families struggled to procure basic necessities, such as food and clean drinking water for their children [2]. My own neighbourhood of Suva Point was without electricity for one week after Winston. This situation was nothing when compared to rural communities which faced far worse difficulties, going weeks and months without electricity and running water [3]. Consider too, that at the time of this publication, more than one year after the event, some are still housed in tents [4]. It is clear that this is the beginning of what is to come for the Pacific. 


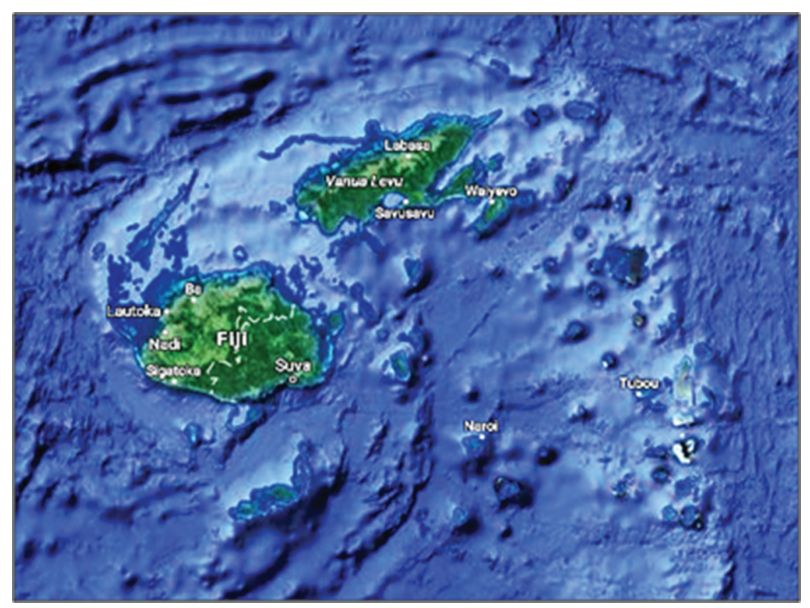

Figure 1: The largest Fijian island, Viti Levu, covers 57\% of the nation's land area and has the two largest urban centres (Suva, the capital, and Lautoka). It also hosts most of the major towns, including Nadi, the site of the international airport, and contains $\sim 69 \%$ of the population (image courtesy of Google Maps; data from [5]).

\section{RISING TIDES IN A CHANGING CLIMATE}

Globally, more than 600 million people, or $8.6 \%$ of the world's population, live in coastal zones (zero to ten metres elevation) which comprises only $2 \%$ of the world's land area. Of these 600 million people more than half, $~ 360$ million, live in urban centres. This amounts to $13 \%$ of the world's urban population living in the highest risk zones of sea-level rise [6].

Pacific Islands Countries and Territories (PICTs), especially the low-lying atoll nations, are presently experiencing the adverse effects of human-induced climate change. PICTs and their urban centres are vulnerable to extreme weather events, such as Winston.

The dense urban and economic centres of PICTs are located in coastal zones and are furthermore vulnerable to rising sea levels and other extreme events. Beyond tropical cyclones, these events include floods, tidal surges, droughts and landslides. Sea-level rise is commonly misunderstood as being a uniform process. However, it is a far more complex process caused by various factors, such as the formation of the earth's crust. Additionally, ocean temperature and salinity reflect regional variability, as well as the gravitational and rotational changes driven by the ice-ocean mass exchange [7-9]. Ultimately, this results in uneven rise and fall in overall sea-level rise, with some areas experiencing an amplified rise, especially in the equatorial region [10].

While these processes have occurred for millennia, humans have affected sea-level rise directly by way of manipulation of ground and surface water flows and indirectly through greenhouse gas emissions that increase global temperatures [11]. These warmer temperatures impact the mass and volume of seawater through increased terrestrial ice melt and warmed ocean temperatures, both of which compound rising global sea-levels.

\section{STAYING AFLOAT IN FIJI'S ECONOMY}

Winston severely affected the lives and livelihoods of 540,000 Fijians or $62 \%$ of the population of the island nation. An estimated 30,369 houses or $22 \%$ of households were destroyed 
or damaged, forcing some 131,000 people into temporary shelter. Further destruction of infrastructure included damage to 495 schools and 88 health facilities [12].

The estimated damage from the cyclone was $£ 1.14$ billion or nearly three billion Fijian dollars, roughly $31 \%$ of the gross domestic product (GDP). With such an extensive loss and the Fijian economy being based primarily on agriculture and tourism, it was unsurprising that the Fijian government issued a month-long state of emergency [13]. Early economic assessments indicated that agriculture (especially sugar that comprised one-third of industry activities) was seriously impacted [6]. Fiji Sugar Corporation Chairman, Abdul Khan, specified 'Our all up losses in the sugar cane industry add up to 163.35 million Fijian dollars. The loss of workers' livelihoods is 53.3 million Fijian dollars' [14]. Unsurprisingly, the tourism industry suffered high cancellation rates of 30\%-40\% immediately following Winston [15]. However, with recovery and reconstruction activities ongoing and the Government prioritising spending to address the emergency needs, the Fijian economy is anticipated to grow by $3.6 \%$ in 2017 and by $3.2 \%$ in 2018 [12].

National statistics indicate that $31 \%$ of Fiji's population lived below the poverty line prior to the devastating effects of Winston [16]. However, in urban areas, such as Suva, the statistics reflect a drop to $19 \%$ of the population, when compared with $43 \%$ in rural areas living below the poverty line. Yet, the statistics belie a more complex reality. I argue that indigenous Fijian or I Taukei lifeways be contemplated and reflected upon when seeking to understand poverty in Fiji pre- and post-Winston. Traditionally, Fijian land is held communally and all members of a village have access to support, and feed themselves from various horticultural and maritime practices. This more nuanced consideration can be summed up by Papuan New Guinean writer Martyn Namorong [17] as he discusses traditional Melanesian life and ideas of poverty: 'The environment was the source of their physical, spiritual and intellectual nourishment. While individuals had certain property rights, such as the ownership of personal artifacts of value, the land was owned communally... Is it poverty, if a rural [man] only wears astanget and does not own a laptop?... How do you define poverty and wealth in this present time when Melanesians live in two realities? We live in the reality of our ancestral land and in the reality of the modern State that exists on that land'.

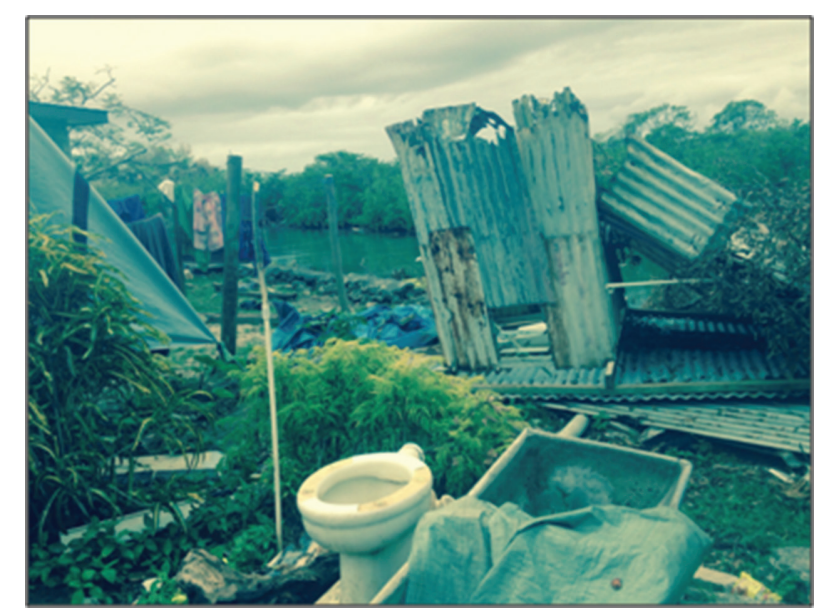

Figure 2: The remains of a family home and bathroom on Qoma Island. Image courtesy of Rowan Gard. 
Statistics indicate that although there are higher rates of poverty in rural areas, those communities are generally better placed to support themselves through traditional subsistence practices. Urban poverty is a pressing concern as individuals and families living in urban centres often lack the means to support themselves. Contributing to this are multiple factors, such as lack of education and skills training, and the harsh fact that $65 \%$ of those in full-time employment in Fiji are earning wages below the basic needs poverty line [18]. Subsequently, the international aid community's understanding and forward movement especially around climate change-related economic and mobility policies must take into account the pressing reality of PICT contemporary urban life, such as in Fiji.

\section{AFTER THE STORM-ON THE GROUND RESPONSE}

In the days and weeks following Winston, I volunteered with Fiji Red Cross and also joined a dozen colleagues at the University of the South Pacific (USP) in gathering and purchasing relief supplies for the fishing community on Qoma Island located northeast of Suva. The island was especially heavily hit and as we arrived via motor boat I stared at the palm trees, their fronds looked to be permanently bent, as if they were experiencing the catastrophe still.

After we had unloaded the relief supplies from the boats, which ranged drastically from freshly baked bread, to plastic sheeting, to a football for the children to play with, we were formally greeted by the village leaders on the concrete foundation slab that had once served as a community gathering space and village hall. We sat in a large circle and were invited to partake in a kava ceremony. Kava, also known as yaqona in Fiji, is a mild narcotic beverage known for its calming effects and is made from combining the root of a shrub, Piper methysticum, with water; kava is used in a range of political, religious and social ceremonies throughout the Pacific. I noted that even the large kava bowl had been damaged with one leg broken off and was propped up with a plastic cup.

Following our formal greeting, I wandered the community in a state of emotional numbness and spoke with the villagers and listened to their Winston or 'the big monster' survival stories. It was clear that the devastation was near-total on Qoma. Many homes and buildings had been stripped to concrete slabs, while other buildings, such as the Methodist Church, which had been the largest building on the island, had a roof that had collapsed and was unsafe to enter. As I surveyed the damage, I was especially touched by the story of one family that had sheltered together in the bathroom, which had partial concrete walls and thus was stronger than the rest of their home. As I spoke with the middle-aged father he shared with me that 'God kept us safe; he is always with us' and it was the love of his family that had enabled him to face the future. Drawing upon faith and family, he was already in the process of rebuilding his family's former home.

After we had spent the afternoon on Qoma, my USP colleagues and I piled back into the boats we arrived in for the short ride back to Viti Levu. On the drive back to Suva, we discussed ways in which the villagers on Qoma, and all of Fiji, could be made more resilient for future extreme weather events. In a previous fieldwork on Qoma, one colleague had encouraged the villagers to plant mangroves, as a means of stabilising their shoreline. Indeed, much of their shoreline was in far better shape than their neighbours, though the villagers' commercial seaweed gardens had been destroyed. They asked for assistance in securing more seaweed starters to replant their aqua gardens, as well as seeds for their terrestrial gardens.

The need to literally rebuild and replant is a powerful one for those who live through the trauma of an extreme weather event, and the need to positively plan for the future is vital. It occurred to me how markedly different sharing seeds and plant starts with a community was 
when compared to more traditional Western aid deployment, which often provided multiple rounds of canned Western food items for immediate consumption. This also reminded me of an observation my colleague Lucie Hazelgrove-Planel, who survived tropical cyclone Pam in Vanuatu noted: 'Does the food aid package as a whole unintentionally include a concept of adaptation to climate change which promotes a Western diet, lifestyle and economy?' [19]. The deeper connotations of this insight are well worth considering as Fiji continues reconstruction and future resiliency measures.

In a more immediate sense, help that comes as standard international aid isn't always necessarily helpful. As was expanded upon by Fe'iloakitau Kaho Tevi [20], a survivor of tropical cyclones Pam and Winston, and a political analyst based in Port Vila, Vanuatu: 'When a disaster happens...they send second hand clothes, they send electrical kitchen appliances to places that don't have electricity. They send high heels, to people who get them and don't have anything to do with them. After the disaster in both Vanuatu and Fiji there was food past its use by date that came. These gifts sit in containers on wharves, and we are not too sure what to do with them. Sometimes we have to sell the clothes, to get some money for the things we need".

In the days and weeks following Winston there were further issues around organising and deployment of relief assets. When speaking with friends, colleagues and community members working in relief deployment, there was more than one account shared of Fijian military personnel consuming and selling supplies intended for Winston victims. It was also known that representatives of the Fijian government had distributed faulty information associated with the national declaration of emergency and aid request, specifically some of the banking account numbers for donations had been altered so that funds were being syphoned into thirdparty accounts. Though this information is anecdotal, I do not doubt it. Some of these corruption charges were briefly acknowledged by the Fiji Independent Commission Against Corruption (FICAC) and the National Disaster Management Office (NDMO) in a press release in March [21]. In relation to this, it is a significant fact that the freedom of the academic and artistic communities as well as the press around issues of investigative journalism and critiques of the government in Fiji remain suppressed by censorship and full blackouts [22], as was the case in the 2014 elections [23]. There is little wonder then that I observed those seeking assistance beyond their own families and trusted community members, to be most comfortable going to their local churches, parishes and faith-based organisations.

\section{THE BUOYANCY OF FAITH - THE ROLE OF FAITH-BASED ORGANISATIONS IN HUMANITARIAN AID}

In the past, religion as well as the role of faith-based organisations (FBOs) have often been ignored by those involved with humanitarian aid and development. Sociologist Kurt Alan ver Beek [24] even went so far as to call it 'a development taboo' after completing a study that explored the void of research on the roles of religious organisations in development. However, in the past 20 years that stigma has lessened, and now the academic community and the wider international aid community have taken a 'religious turn' of sorts exploring in greater depth the role FBOs play in humanitarian aid [25].

Though FBOs have a long history of humanitarian work, ranging from Christian hospitals to Hindu meal programmes, a recent proliferation in religious charities, NGOs and other associations have flourished. Importantly, the World Bank has estimated that as high as 50\% of all health and educational services globally are provided by FBOs [26] and further evidence for the growth of FBOs can be found in the dramatic increase in US government 
funding from 2001 to 2005, where in that time period an increase of $10.5 \%$ to $19.9 \%$ occurred [26]. The World Bank's 2000 study entitled Voices of the Poor concluded that many people in lower socioeconomic conditions demonstrated more confidence in religious organisations than other secular, governmental or military governing bodies [27].

Presently, there are some 33,500 international NGOs in the world with 3,183 being granted consultative status with the Economic and Social Council (ECOSOC) in the United Nations (UN) [28]. Embedded within Article 71, Chapter X of the UN's Charter, authority is given to 'make suitable arrangements for consultation with non-governmental organizations which are concerned with matters within its competence' [29]. This is advantageous as many FBOs often have deeper histories than other NGOs, which can in turn strengthen their connections with local communities. In times of crises, FBOs are able to build on established foundations of trust and expedite response in emergency situations. I observed this first-hand while in Fiji, in particular whilst engaging with the congregation of Saint Luke's Anglican Church and the aid they provided to the wider community following Winston. However, it should be noted that past relationships and pre-established sympathies might impact the FBOs' abilities to engage with the wider community in an unbiased and unpolitical manner given the competitive dynamics of religious organisations in some communities [30]. Nevertheless, an increased integration of FBOs at all levels of response to extreme weather and climate change may prove advantageous, as they have much to offer the communities in which they are embedded, as well as the wider humanitarian community.

\section{STRINGS ATTACHED - THE POLITICS OF HUMANITARIAN AID}

The international response to Cyclone Winston was significant not just from the pressing humanitarian relief aspect, but also the political influence exerted by various nations vying for Fiji's affections. Australia committed \$35 million dollars as assistance to recovery, including supplies and health services to over 200,000 people. The HMAS Canberra and over 1,000 Australian Defence Force and humanitarian personnel were deployed with 341 tonnes of relief supplies; including 30,000 litres of drinking water; 10,000 hygiene kits; and 7,000 shelter kits; as well as undertaking repairs to seven primary schools, two medical centres and one secondary school [31].

Australia's Department of Foreign Affairs and Trade (DFAT), with the support of Foreign Minister Julie Bishop, have committed to supporting Fiji in a long-term recovery plan. Australia has prominently highlighted their humanitarian efforts with a spokesperson noting 'Australia has a longstanding friendship with Fiji and we acted swiftly to support the Fiji Government response to the devastation of Tropical Cyclone Winston. Australia remains the largest donor to the response effort and we will continue to be there for the long-haul to help Fiji recover' [32].

Political tensions following the Fijian coups in 2000, and again in 2006, and the slow governmental response to restoring democracy, have led to a strained relationship with the governments of Australia and New Zealand. In 2014, Australia lifted the last restrictions on the Fijian government. Fiji was also reinstated in 2014 into both the Commonwealth and Pacific Island Forum. These shifts likely enabled Australia and New Zealand to provide substantial aid following Winston and politically re-engage with the Fijian government after an approximate 15-year gap. Further, the New Zealand Prime Minister John Key, described the aid thus: 'New Zealand's response to Cyclone Winston is shaping up to be our largest humanitarian response in the Pacific' [33]. Although disheartening it may be to consider the political opportunities natural disasters yield, especially with an eye to the future of climate 
change in the Pacific, the international aid Fiji received following Winston is deserving of critical consideration.

Shortly after my arrival in Fiji in January of 2016, 20 shipping containers containing weapons arrived in the Port of Suva from Russia. It seemed likely that this shipment was intended for use by Fijian peacekeeping forces, given that 45 Fijian UN peacekeepers were captured by the al-Nusra Front in Syria in 2014 [34]. It has been suggested that the peacekeepers' capture was partially related to obsolete military equipment and technology [35]. The recent donation of arms to Fiji from Russia likely was noted by the international community, as it may well signify a greater geopolitical realignment by Fiji. Significantly, while still operating under coup sanctions by the international community, the Prime Minister Bainimarama fostered a 'Look North' political mind-set within Fiji and turned to other nations, such as Russia and China, less concerned with the state of democracy and human rights in Fiji. Political commentators have also noted that Russia is currently using 'chequebook diplomacy' in the Pacific. For example, in 2008, Nauru, Vanuatu and Tuvalu recognised Georgia, Abkhazia and South Ossetia following a Russian invasion and border reconfiguring, following international aid support from Russia [35]. And again in 2014, these PICTs along with Fiji and Tonga, recognised the annexation of Crimea [35].

While Australia and New Zealand continue to dominate aid relief in the South Pacific, Russia and China's continuing contributions are notably expanding. While discussing the Fijian economy one afternoon, a Fijian friend referred to the foreign powers presence in the islands as 'sharks in the water.' Consequently, the symbolic significance of aid warrants attention, especially as it reflects blood in the water and the evolving global political multipolarity and regional power potentially in flux.

\section{BUILDING A BETTER TOMORROW - UNDERSTANDING MOBILITY AND INCOME DIVERSIFICATION}

In an increasingly warming world frequently cited figures estimate that by 2050 the number of people forced to move primarily because of climate change will range between 200 million [36] and 1 billion [37]. Much of the literature to date on mobility in response to environmental degradation often assumes that migrants are a monolithic group making similar responses to environmental crises and moving to international destinations as yet unknown. This assumption is out of step with a more nuanced view of migration; a view in which migration is a vital adaptive strategy in response to environmental and socioeconomic mutability. If we are to work towards a more comprehensive view of mobility and migration, then understanding the duration, destination and composition of migration flows is essential for achieving a deeper knowledge of their impact on both origin and destination communities, as well as ways in which policy can successfully support individuals and communities on the move [38, 39].

Extreme weather events force people to leave their homes as they are no longer habitable. Yet, we know that most displaced people return to their homes as soon as possible, seeking to literally rebuild their lives [40-43]. Increasing levels of mobility in response to extreme weather events are likely, though the mobility may be cyclical in nature. For example, many Fijian colleagues who lived in Suva returned to their home villages following Winston to assist in the rebuilding of rural communities with familial connections. However, within weeks of Winston, many Fijians returned to the altered normality of a post-Winston world within their respective rural or urban spheres. Ultimately, mobility is a part of the solution to climate change and extreme weather events, not the problem. 
Assumptions are often put forward that transnational migration is the major form of migration, when this is simply not true. Consider that in numerous conversations with Fijian friends, colleagues, relief workers and community members not a single person mentioned emigrating after Winston, even in lengthy discussions on climate change and the bleak future many PICTs faced with regard to increasing extreme weather events and rising sea level. Although, it should be noted that Fiji does have advantageous highland topography when compared with other lower-lying PICTs. However, contradictory perspectives put forward by American and European politicians around concerns of migrants from low-income nations arriving on wealthy shores in 'swarm(s)' [44] is oversimplified and incomplete, not to mention based on xenophobia and racism [45], especially when it comes to issues of environmental change [38]. In my experience, few Pacific Islanders wish to leave their island homes. Adaptation to limited-range and cyclical mobility within national boundaries reduces the necessity to move great distances away from impacted zones and enables those affected by extreme weather disruptions to return more quickly to their homes and communities.

According to the International Institute for Environment and Development 'There is growing evidence suggesting that mobility, in conjunction with income diversification, is an important strategy to reduce vulnerability to environmental and non-environmental risksincluding economic shocks and social marginalization' [38]. Development and policy that support mobility and differentiates the variability within migration, is an important step forward. For example, the European Union (EU)-funded Pacific Climate Change and Migration (PCCM) project, in partnership with the International Labour Organisation (ILO) and the United Nations Development Programme (UNDP) has been recently implemented by the United Nations Economic and Social Commission for Asia and the Pacific (UNESCAP), and is positively supporting PICTs such as Kiribati, Nauru and Tuvalu, which are subject to future sea inundation [46]. The primary goals of the PCCM which commenced in 2014 are twofold, (1). 'To increase protection of individuals and communities that are vulnerable to climate change displacement and migration through targeted national and regional policies; and (2) To increase labour mobility opportunities for Pacific Islanders, through well-managed labour migrations schemes' [46]. The former President of Kiribati, Anote Tong, speaking in regards to the realities of slow-onset climate change and the PCCM project noted: 'We are providing options for those that want to migrate now as a matter of choice, to do so as worthwhile citizens. We are providing training [and] up-skilling so that they can apply to different countries to seek migration status on merit' [47].

Attempting to predict human actions and agency in the advent of climate change and extreme weather events is tremendously challenging. It can be useful to extrapolate migration patterns from previous natural disasters, as a means of making analogous parallels. Studies [48-50] of migration patterns within wealthier, social-networked and better-educated groups point to these groups remaining mostly unaffected by environmental degradation, while younger groups with fewer dependents and possessions are increasingly likely to permanently resettle in new areas than those with land ownership in the impacted zones. Although this should not be confused with impoverished groups who have limited ability to invest in migration and are therefore less likely to employ mobility as an adaptation strategy. For example, 'Approximately 10,000 people across Kiribati, Nauru, and Tuvalu attempted to migrate between 2005 and 2015 but were unable to do so, primarily due to financial constraints' [39]. For those too poor to migrate who are dealing with both short-term environmental degradation and slow-onset climate change the ability to survive will be determined by the accessibility to local opportunities for income diversification. Simultaneously, 
those individuals and groups who are socioeconomically and politically marginalised will be least able to compete for the increasingly sought after resources and opportunities.

\section{THE ANXIOUS EDGE OF NOW - CONCLUSIONS \& FUTURE RESEARCH}

The main purpose of this analysis was to give a first-hand account of the impacts of extreme weather in Fiji, the roles FBOs can play in community resiliency schemes, and to further elucidate the role of mobility within short- and long-term climate change situations. To that end, research that explores analogous parallels with the predicted impacts of climate change suggests that environmental degradation does not necessarily result in migration. Where mobility does occur, as with extreme weather events, it is often shorter in duration and distance, similar to what I experienced and observed in Fiji. My findings mirror the behaviour of previously researched episodes of drought in other regions of the world. However, in regards to slow onset climate change and rising sea levels, considerably less is known. The total PICTs populations required to move in the Pacific - most especially citizens of Kiribati, Nauru, Tuvalu and the Marshall Islands - will greatly depend on adaptation and resiliency initiatives and the support and planning of wider international strategies [39]. In the future, there is an opportunity to research in greater depth the correlations between environment, cyclical mobility and income diversification within national boundaries in the Pacific, as these types of trends and movement tend to go undocumented in national census data [38].

Finally, predicting the impact of climate change on population distribution and movement is fraught with difficulties. However, it seems unlikely that the political alarmist claims of a wave of millions of environmental refugees will occur. Further, a paradigm shift is need when understanding migration, as it is a part of the solution not the problem. Many migration management policies try to control the volume and types of population movement, when they would be wise in supporting more nuanced migration patterns that result from environmental degradation, economic growth or crisis, while simultaneously integrating appropriate cultural and faith precepts in an attempt to support individuals, families and communities on the move.

\section{ACKNOWLEDGEMENTS}

My research was generously made possible by Dr. Tony Crook and by funding from the University of St Andrews and was further supported by the European Consortium for Pacific Studies (ECOPAS) with funding from the European Union (EU). I owe tremendous debt to my co-author Dr. Joeli Vitayaki for his invaluable advice and assistance from my first days in Fiji through the present, and for generously and cheerfully sharing his illimitable knowledge of marine conservation. I thank too, the Happy Home Trust for their generous hospitality during my time in Fiji, providing me with sanctuary during tropical cyclone Winston. Finally, I am thankful to Dr. Elizabeth Minor, Laura Pond and Ricky Young for their friendship and contributions to this project.

\section{REFERENCES}

[1] Westcott, L., Tropical cyclone winston slams fiji with 200 MPH winds, kills 21. Newsweek, 22 February 2016, available at, http://europe.newsweek.com/fiji-tropicalcyclone-winston-photos-429070?rm=eu (accessed 23 January 2017)

[2] Bolatagici, L., Food supply runs short. The Fiji Times, 21 May 2015, available at http:// www.fijitimes.com/story.aspx?id=354571 (accessed 15 December 2016).

[3] Round, S., Cry for more help from remote Fijian village. Radio New Zealand, 12 April 2016, availablea at http://www.radionz.co.nz/international/pacific-news/301293/cryfor-more-help-from-remote-fijian-village (accessed 27 November 2016). 
[4] Round, S., Resilience amid the struggle-one year on from Cyclone Winston. Radio New Zealand, 20 February 2017, available at http://www.radionz.co.nz/international/ pacific-news/324871/resilience-amid-the-struggle-one-year-on-from-cyclone-winston (accessed 20 February 2017)

[5] Fiji High Commision. Wellington 6011, New Zealand, available at http://www.fiji.org. nz/about-fiji/ (accessed 15 January 2017)

[6] McGranahan, G., Balk, D. \& Anderson, B., The rising tide: assessing the risks of climate change and human settlements in low elevation coastal zones. Environment and Urbanization, 19(1), pp. 17-37, 2007. https://doi.org/10.1177/0956247807076960

[7] Farrell, W. \& Clark, J., On postglacial sea level. Geophysical Journal International, 46, pp. 647-667, 1976.

https://doi.org/10.1111/j.1365-246X.1976.tb01252.X

[8] Mitrovica, J., Tamisiea, M., Davis, J. \& Milne, G., Recent mass balance of polar ice sheets inferred from patterns of global sea-level change. Nature, 409, pp. 1026-1029, 2001. https://doi.org/10.1038/35059054

[9] Mitrovica, J., Gomez, N. \& Clark, P., The sea-level fingerprint of West Antarctic collapse. Science, 323, p. 753, 2009.

https://doi.org/10.1126/science.1166510

[10] Tamisiea, M., Mitrovica, J., Davis, J. \& Milne, G., Long wavelength sea level and solid surface perturbations driven by polar ice mass variations: fingerprinting Greenland and Antarctic ice sheet flux. Space Science Rev, 108, pp. 81-93, 2003.

https://doi.org/10.1023/A:1026178014950

[11] NOAA (National Oceanic and Atmospheric Administration). U.S. Department of Commerce. 2016. Global ocean heat and salt content, available at www.nodc.noaa.gov/ OC5/3M_HEAT_CONTENT (accessed 28 January 2017)

[12] Asian Development Bank, Fiji: Emergency Assistance for Recovery from Tropical Cyclone Winston. 2016. Available at: https://www.adb.org/projects/50181-001/ main\#project-pds (accessed 15 January 2017).

[13] The Fijian Government. Suva, Fiji, available at http://www.fiji.gov.fj/Media-Center/ Press-Releases/FIJIAN-GOVERNMENT-ESTABLISHES-DISASTER-RELIEFFUND.aspx (accessed 18 January 2017)

[14] Qalubau, P., Sugar Industry records \$163.35 million loss. Newswire, 29 May 2016. Available at: https://www.newswire.com.fj/national/tc-winston/sugar-industry-records163-35-million-loss/ (accessed 12 November 2016)

[15] Dateline Pacific. Radio New Zealand, 24 February 2016. Available at: http://www. radionz.co.nz/international/programmes/datelinepacific/audio/201790617/fiji's-tourism-industry-takes-big-hit-following-cyclone-winston (accessed 12 January 2017).

[16] Fiji Bureau of Statistics. Suva, Fiji. Avilable at: http://www.statsfiji.gov.fj/statistics/ (accessed 17 January 2017)

[17] Namorong, M., The melanesian way: the definitions of leadership and poverty are in direct contrast with western lifestyle. The Melanesian Way, 1 October 2016. Available at: https://melanesianwaypacific.blogspot.co.uk (accessed 12 February 2017).

[18] Barr, K., Economic growth for each one of us. The Fiji Times, 1 November 2014. Available at: http://www.fijitimes.com/story.aspx?id=284819 (accessed 18 December 2016)

[19] Hazelgrove-Planel, L., Cyclone pam from the field: adapting to climate change? Anthropology Today, 31(6), 2015.

https://doi.org/10.1111/1467-8322.12213 
[20] Anglican Communion News Service, Church to develop disaster strategy as Pacific islands disappear. Episcopal News Service, 11 May 2016. Available at: http://episcopaldigitalnetwork.com/ens/2016/05/11/church-to-develop-disaster-strategy-as-pacificislands-disappear/ (accessed 18 February 2017)

[21] The Fiji Independent Commission Against Corruption (FICAC). The Fiji Sun. 5 March 2016. Available at: http://fijisun.com.fj/2016/03/05/ficac-on-lookout-for-corrupt-practices-on-the-back-of-cyclone-winston/ (accessed 17 November 2017).

[22] Simmons, M., No media freedom in Fiji while decree still in place, says Prasad. Asia Pacific Report, 5 May 2016. Available at: http://asiapacificreport.nz/2016/05/05/nomedia-freedom-in-fiji-while-decree-still-in-place-says-prasad/ (accessed 18 February 2017).

[23] Agence France-Presse (AFP). Fiji imposes draconian media blackout ahead of this week's poll. The Australian, 15 September 2014. Available at: http://www.theaustralian.com.au/news/world/fiji-imposes-draconian-media-blackout-ahead-of-this-weekspoll/news-story/a11a2823ff456f93c0f83ab024b3440d (accessed 14 January 2017).

[24] Alan ver Beek, K., Spirituality: a development taboo. Development in Practice, 10(1), p. 31, 2000.

[25] Petersen, M., International religious NGOs at the UN: a study of a group of religious organizations. The Journal of Humanitarian Assistance, 17 November 2010.

[26] James, R., What is distinctive about FBOs?, The international NGO training and research centre (INTRAC). Praxis Paper, 22, p. 7, 2009.

[27] Narayan, D., Chambers, R., Shan, M.K. \& Petesch, P., Voices of the Poor. World Bank, 2000.

[28] Boli, J. \& Brewington, D., Religious organizations in religion. Globalizaiton and Culture, p. 207, 2007.

[29] United Nations Charter, chapter X, Article 71, available at www.un.org, (accessed 2 February 2017)

[30] Newland, L., Fiji in Globalization and the Re-Shaping of Christianity in the Pacific Islands, pp. 383-385, 2006.

[31] Australian Government. Department of Foreign Affairs and Trade. Barton ACT 0221 Australia. Available at: http://dfat.gov.au/aid/topics/investment-priorities/buildingresilience/humanitarian-preparedness-and-response/tc-winston/Pages/default.aspx (accessed 12 January 2017)

[32] Wyeth, G., After cyclone winston, focus on fiji's regional relationships. The Diplomat Magazine, 6 April 2016. Available at http://thediplomat.com/2016/04/after-cyclonewinston-focus-on-fijis-regional-relationships/ (accessed 10 December 2016).

[33] Cyclone Winston: NZ Government offers extra aid injection to help Fiji. New Zealand Herald, 1 March 2016. Available at http://www.nzherald.co.nz/nz/news/article.cfm?c_ id=1\&objectid=11598113

[34] ABC/Reuters. Fijian peacekeepers released by Syrian militant group Jabhat al-Nusra, two weeks after capture in Golan Heights: UN. ABC News. 12 September 2014. Available at: http://www.abc.net.au/news/2014-09-11/captured-fiji-peacekeepers-releasedun-says/5737772 (accessed 17 January 2017).

[35] Madaus, R., The bear returns to the south pacific: Russia sends arms to Fiji. The Diplomat Magazine, 9 April 2016. Available at: http://thediplomat.com/2016/04/the-bearreturns-to-the-south-pacific-russia-sends-arms-to-fiji/ (accessed 15 November 2016).

[36] Myers, N., Environmental refugees: an emerging security issue. Proceedings of the 13th Economic Forum, May 2005. 
[37] Christian Aid, Human Tide: The Real Migration Crisis. Christian Aid Report. May, 2007. Available at: https://www.christianaid.org.uk/Images/human-tide.pdf, (accessed 2 January 2017)

[38] Tacoli, C., Crisis or adaptation? migration and climate change in a context of high mobility. Environment \& Urbanization, 21(2), pp. 513-525, 2009. https://doi.org/10.1177/0956247809342182

[39] United Nations, Economic and social commission for asia and the pacific. pacific climate change and migration project. Suva, Fiji. Available at: http://www.unescap.org/ subregional-office/pacific/pacific-climate-change-and-migration-project (accessed 5 February 2017)

[40] Perch-Nielsen, S. \& Bättig, M., Exploring the link between climate change and migration. Proceedings of the 6th Open Meeting of the Human Dimensions of Global Environmental Change Research Community, October 2005.

[41] Raleigh, C., Jordan, L. \& Salehyan, I., Assessing the impact of climate change on migration and conflict. Paper presented at Social Dimensions of Climate Change, Social Development Department, the World Bank, March 2008.

[42] GECHS, Disaster Risk Reduction, Climate Change Adaptation and Human Security, Report 2008:3, GECHS - Global Environmental Change and Human Security, University of Oslo, Oslo, 2008.

[43] Piguet, E., Climate change and forced migration. Research Paper No 153, New Issues in Refugee Research Series UNHCR, Geneva, 2008.

[44] Elgot, J., How David cameron's language on refugees has provoked anger. The Guardian, 27 January 2016. Available at: https://www.theguardian.com/uk-news/2016/jan/27/ david-camerons-bunch-of-migrants-quip-is-latest-of-several-such-comments (accessed 12 January 2017)

[45] Yakushko, O., Xenophobia: understanding the roots and consequences of negative additudes toward immigrants. Educational Psychology Papers and Publications, University of Nebraska, Lincoln, 1 January 2009

[46] UNESCAP. United Nations. Economic and Social Commission for Asia and the Pacific. Climate Change and Migration in the Pacific: Links, attitudes, and future scenarios in Nauru, Tuvalu, and Kiribati, 2016, available at http://www.unescap.org/sites/default/ files/PCCM\%20-\%20\%20Survey\%20Fact\%20Sheet.pdf (accessed 20 November 2016).

[47] Singh, D., Analysis: Pacific climate change and migration project addresses climate induced migration. The Fiji Sun, 29 October 2015. Available at: http://fijisun.com. fj/2015/10/29/pacific-climate-change-and-migration-project-addresses-climateinduced-migration/ (accessed 16 January 2017)

[48] McLeman, R. \& Smit, B., Climate change, migration and security, Commentary 86, Canadian Security Intelligence Service, Ottawa, 2004.

[49] Massey, D., Axinn, W. \& Ghimire, D., Environmental change and out-migration: evidence from Nepal. Population Studies Centre Research Report 07-615, Institute for Social Research, University of Michigan, Ann Arbor, 2007.

[50] Morrissey, J., Environmental Change and Forced Migration: A State of the Art Review, Refugee Studies Centre, Oxford Department of International Development, University of Oxford, Oxford, 2009. 